\title{
Black Faces in White Spaces: Black Women's YouTube \\ Channels in Brazil as Fortalecimento
}

\author{
ALIDA PERRINE \\ University of Texas, Austin
}

\begin{abstract}
A large and growing network of black women YouTubers in Brazil mobilize strategies of fortalecimento, a term used by some women to refer to how they prepare themselves to face the barriers created by the gendered racial hierarchy of Brazilian society. In this article, I examine these YouTube channels and the tactics black women use to increase their own visibility, to value black aesthetics, and to denounce racist and sexist acts or representations. Furthermore, I consider the importance of physical spaces, such as production studios, for YouTube success, and how black women negotiate material spaces as well as the video sharing platform to maximize their visibility and encroach on predominantly white spaces of cultural production. Using theories of intersectionality, representation, and subjecthood, I examine how these women use (virtual) communities to re-signify and pluralize black womanhood in Brazil.
\end{abstract}

Keywords: Racism, sexism, social media, representation, cultural resistance

When Nátaly Neri, a 21-year-old black college student, started her YouTube channel in 2015, it was one among thousands of other channels containing do-ityourself videos about sewing and hairstyles. Scrolling through her videos, one finds showcases of thrift-store finds transformed into the unique fashion that defines Neri's style, as well as detailed documentation of her transitions from braids to dreads and beyond. For many young black women like Neri with channels on YouTube, not just in Brazil but throughout the diaspora, haircare and styling is a common entry point to the practice of self-vlogging. While devoting 
so much attention to celebrating natural styles of black hair is itself an important tool of racial valorization, many of these YouTubers insert other strategies of gender and racial affirmation into their regular vlogging practices, to greater or lesser extents. A closer look at Neri’s channel, “Afros e Afins,” reveals that from the very beginning, it has been a highly politicized space not just of selfaffirmation and racial empowerment, but of carefully articulated social and political critiques of a racist and sexist society.

Neri is one of a large and growing network of black women YouTubers in Brazil who are mobilizing various strategies to strengthen themselves, their communities, and to forge spaces in which they can survive in a society that is largely hostile to them. In this article, I examine these YouTube channels, in addition to other online content such as blogs, in order to demonstrate how content producers employ tactics to increase their own visibility as black women, to value black aesthetics, and to denounce racist and sexist acts or representations. Furthermore, I explore physical spaces that these women utilize in conjunction with online spaces to fulfill their needs as content creators aimed at a particular audience of young black women to enact these strategies of resistance and survival. How do these women negotiate these online and physical spaces? How necessary are the physical spaces for online success? In what ways are these young black women occupying traditional white spaces with their presence online and in video studios? I analyze YouTube channels created by users who valorize themselves and their audiences as black women in opposition to mainstream exclusion and negative representation based on race and gender in Brazilian culture and society. Using theories of intersectionality, representation, and subjecthood I frame the initiatives of these young YouTubers as using (virtual) communities to re-signify and pluralize black womanhood in Brazil.

I take an intersectional approach to theorizing identity that privileges positionality. While understanding the theoretical problems associated with finite identity categories, identifying as black women is an important and powerful tool for facing the realities implied by that social position. Black feminist scholars throughout the diaspora have called attention to the importance of theorizing through their unique perspectives and experiences as black women. For example, Brazilian philosopher Djamila Ribeiro builds on feminist standpoint theory to offer lugar de fala as a critical aspect of black feminist scholarship. In her book 
O que é lugar de fala?, she offers the ideas of Linda Alcoff to demonstrate the need for using identity categories:

[P]ara descolonizarmos o conhecimento, precisamos nos ater à identidade social, não somente para evidenciar como o projeto de colonialização tem criado essas identidades, mas para mostrar como certas identidades têm sido historicamente silenciadas e desautorizadas no sentido epistêmico, ao passo que outras são fortalecidas.” (28-29)

This is key to understanding how even though categories like race were produced by colonization, it is essential to recognize them as social realities with lasting material effects.

Black women use YouTube videos to create spaces for their own voices to be heard. The ideas of black women have been marginalized, silenced, and forgotten, so taking up space to discuss issues that concern them takes a step towards countering that invisibilization. That is why visibility is one of the key strategies of black women online content producers. The source of their invisibilization comes from being a black woman in Brazil's sexualized-racist society, and the source of their visibility comes from mobilizing the very markers attached to black womanhood, such as hair, skin color, connections to African influences in food, clothing or spirituality, and daily experiences of gendered or sexualized racism. These women manufacture their own images, affirm themselves as valuable, and share that affirmation with a community of followers and fellow content producers.

\section{Social Media and Fortalecimento}

Social media research presents unique opportunities and challenges. Many scholars have utilized the vast content available on websites such as Facebook, Twitter, and YouTube, each offering different insights about the ways users produce and interact with these media. José Van Dijck provides a critical history of social media use and the transition from a participatory culture to a culture of connectivity. He includes chapters on Flickr, Facebook, YouTube, Wikipedia, and Twitter to show how web technologies and human sociality have affected 
Perrine

each other. His assessment that "social media services can be both intensely empowering and disturbingly exploitative” (Djick 18) helps me structure a nuanced analysis of the role of Neri's channel and her own self-reflections on capital and blackness. Jean Burgess and Joshua Green study the empowerment/exploitation dichotomy more in depth, particularly on YouTube, in their research on the way the platform is mobilized for self-representation. Their essay on "entrepreneurial vlogging" addresses central issues of how YouTube channels can unsettle divides between professional/amateur and consumer/producer (90). Alongside content analysis of the videos on Neri's and others' channels, these considerations help to contextualize such channels as part of a larger disruption in the way in which culture is produced and consumed. Both books are essential starting points for social media research, but from a largely US-centered perspective.

Access to Internet in Brazil has steadily increased in recent years. 69.3\% of total households in Brazil had access to Internet in 2016 ("Acesso à Internet [...] análise” 16), up from 54.9\% in 2014 and 48\% in 2013 (“Acesso à Internet [...] 2014” 40). However, access was much less in rural areas, ranging from $22 \%$ (in Brazil's northern region, composed largely of the Amazon rainforest) to 46\% (in the southern region) (“Acesso à Internet [...] análise” 16). The most frequent reason given for not having Internet at home was lack of interest (34.8\% of households without Internet) (“Acesso à Internet [...] análise” 17). However, expense was also cited as a barrier for $33.1 \%$, and in $20.7 \%$ of households there was nobody who knew how to use the Internet (“Acesso à Internet [...] análise” 17). Furthermore, $24.6 \%$ of households without Internet in rural areas stated unavailability of services in their area (“Acesso à Internet [...] análise” 17). For households with Internet, 97.2\% used cell phones, and this technology was used exclusively in 38.6\% of homes (“Acesso à Internet [...] análise” 20). Internet use was directly correlated to level of education. More than 95\% of Brazilians with at least some college education used the Internet, while less than $40 \%$ of Brazilians who did not finish elementary school used the Internet. So, while factors such as region, urban versus rural, age, and level of education still contribute to accessibility to Internet usage, the tendency has been of increasing availability across demographics.

Some researchers have investigated the role of social media in Brazil, particularly as they are used by favela-dwellers, including those using LAN 
houses to connect to the Internet (Ali); with regard to the issue of bridging a digital divide (Nemer); or with a focus on blog content production in favelas (Holmes). Ali shows the importance of considering social media use in bridging the digital divide due to its "capacity [...] to attract a wide user base, stimulate content creation, promote basic [Information Communication Technology] skills, and foster participation and democratization in developing nations” (212). These studies provide important documentation of varied roles of social media in Brazil, but despite their focus on favelas, they do not center racial identities or discourses. In contrast, my work focuses almost exclusively on social media as a reflection of racial exclusion in Brazilian society and as a tool for black women to reject such exclusion. Ali also demonstrated the effectiveness of widespread social media usage for protests in Egypt. The connection between political and social activism and online social networking has been researched by other scholars in relation to protests in the United States (Bonilla and Rosa), Mexico, and Brazil (Spiro and Monroy-Hernández).

Bonilla and Rosa utilize as a fieldsite the hashtag \#Ferguson that was used after the killing of black teenager Michael Brown by a police officer. Through their analysis, Bonilla and Rosa draw attention not only to the capacity of social media for disseminating information about particular events, but also the rise of digital protest as an important alternative tool for groups, such as African Americans, whose protests frequently are represented in the media as riots (8). They conclude that examining hashtags is one important piece of understanding social movements like those that have arisen in the United States around the publicized police shootings of unarmed black men, and that it is important to consider the way online and offline forms of protest interact with each other. My research mobilizes this approach by considering the full range of activities of young black women in Brazil, on social media, in physical spaces of community gathering, and in the streets.

Many scholars have been interested in social media content, especially on blogs, created by black internauts outside of Brazil; special attention has been paid to the United States (Steele), Britain (Gabriel; Sobande), and in Cuba (Sierra-Rivera). Francesca Sobande has analyzed the impact of YouTube content created by black women on black women millennials in England and Scotland. She finds that content related to natural hair leads to deeper reflections on identity and blackness, and that the presence of black women on YouTube presents an 
alternative to representations in mainstream British media (or lack thereof). She also emphasizes the sense of community that viewers feel when encountering a variety of videos created by women who look like them in different parts of the world. The similar types of content of the English-language videos she discusses with those in Brazil analyzed in this article suggest that diaspora is fundamental when thinking about how black womanhood is being resignified in the twentyfirst century inside and outside of Brazil.

Throughout this article, I employ the terms fortalecimento, valorization, affirmation and empowerment to refer to black women's relationship to themselves, their bodies, their cultural practices, and other members of their families and communities. Guided by the terminology deployed by the women who protagonize this article and who use the words empoderar, empoderamento, and empoderada to refer to a variety of practices and experiences, I use the terms empowerment or self-empowerment to describe how women are taking control over the way they tell their own stories and craft their own representations. Joice Berth's text, O que é empoderamento? is a part of Ribeiro's Feminismos plurais series, meant to make feminist concepts accessible to wider audiences. Berth explores the use of the term empoderamento, a neologism taken from the English empowerment (18). Given that empowerment has often been used to describe a process of providing tools or resources to a disenfranchised group in order for them to be able to improve their own social situation, some have considered this to be patronizing toward marginalized groups. In Brazilianizing the term, however, Berth also recalls Paulo Freire's use of empoderamento as something that must come from within a community.

I prefer valorization and affirmation to refer to the practices by which black women value themselves (and each other) as individuals rather than merely as a function of their social status. These practices help women to take ownership of their bodies, their sexualities, and their aesthetic preferences, and they also commonly involve women explicitly valuing their creativity and intellect. In the context of the daily barrage of stereotypical and negative images of black womanhood in Brazil, the mere fact that black women produce and disseminate their own narratives on YouTube, blogs and other social media amounts to a radical act of anti-racist and anti-sexist resistance. I find the term fortalecimento to be the most productive way to discuss black women's shared practices and strategies on social media. Some women use fortalecimento or fortalecer to refer 
to the ways they have to prepare themselves to face the barriers created by the gendered racial hierarchy of Brazilian society. I use fortalecimento to describe the ways in which practices of affirmation can have an inward effect while also having an impact on other women and girls who engage this content. I use it to point to the ways women strengthen each other collectively through practices made possible by a shared black female identity.

\section{Black YouTube and Visibility}

The video-sharing website YouTube was created in 2005 and rapidly grew in terms both of number of users and number of videos uploaded each day to the website. Google purchased YouTube in 2006, and the video sharing platform has continued to grow consistently since then. Worldwide and in Brazil, YouTube is the second most accessed website (Fisher). The website does not require a log-in to view the more than seven billion uploaded videos available. Creating an account allows users to like or dislike and comment on videos, subscribe to channels, and upload videos to their own channels. YouTube offers various incentives for users to increase subscribers to their channels in the form of access to resources designed to improve quality of their content. The most popular YouTube channels in Brazil and in the world, with tens of millions of subscribers, have pop music content or content from popular television shows, or content related to videogames such as playthroughs with or without commentaries. However, there are many extremely popular channels that follow a more typical vlogging format, characterized by a lightly edited video of a YouTuber speaking directly to the camera. The channels that I analyze here follow this general format and feature young, black Brazilian women in their twenties and early thirties.

I have narrowed my analysis of YouTube content to focus on videos posted during the month of November 2016. I chose this moment because November is officially black consciousness month in Brazil, and because of the polarization of Brazilian society and politics taking place at this time. Brazil was sent reeling by the impeachment of President Dilma Rousseff in June 2016, and it was clear to most Brazilians by the end of that highly politicized process that significant setbacks for women, poor families, and people of color were on the horizon. The administration that followed quickly worked to limit public funding in the areas of health, education, and public safety, while also rolling back legal protections 
for workers. Despite this bleak political backdrop, black women YouTubers managed to produce lively, engaging, and uplifiting content for that year's black consciousness month.

I started following forty YouTube channels that I discovered through several websites including Blogueiras negras, Mundo negro, and Afroflix, as well as through the channels themselves, which often link to others. What the channels share is an engagement with the experience of being a black woman in Brazilian society. The women seek to affirm the ability of their viewers to value themselves as beautiful, through hair and makeup tutorials, as a body worth caring for, through exercise and diet tips, and as subjects with valid experiences, through frank discussions about race and gender. I am interested in the way channels function as a means of self-valorization of the channel creators on the personal level, and as a source for race and gender fortalecimento of viewers and fellow YouTubers on the level of the online community.

Many of the channels that I follow, including Neri's channel, are part of a small network of YouTubers based in São Paulo. Because the YouTubers know each other IRL (in real life), they often create collaborative videos, inviting each other to appear as guests on one another's channels. Neri did this on a large scale in November 2016, creating a series called YouTube negro, in which she invited different guests for talk-show style videos that addressed different topics to do with black women, including their sexuality and presence in popular music. Neri's eight-video series united by the hashtag \#YouTubeNegro depended on the participation of one or two fellow YouTubers in each video. To produce this series, Neri made use of the YouTube Space in her hometown of São Paulo, and she used a traditional multi-camera talk-show format for each video. The series was the most polished and professional project on her channel up until that point, and it even included a promotional video for the series. More impressive still, the eighth and final video in the series featured the samba diva Elza Soares. Soares had been extremely popular in the 1960s and 1970s, and she had regained the spotlight in 2015 with the release of a new album, A mulher do fim do mundo. This series exemplifies the wide range of strategies that YouTubers use to affirm themselves and their communities, including collaboration, valuing aesthetics, and inspiring future generations.

The importance of collaboration is a theme common to black women YouTubers. They link to each other's channels; they invite each other to appear 
in videos; they share hashtags. Not only is this a strategy for collective improvement as black women, it is a strategy that is specific to YouTube and significantly expands each channel's viewership. In their examination of the "YouTube star" phenomenon, Burgess and Green highlight the ability of such "entrepreneurial vloggers" to collaborate with others and participate in YouTube's sense of community:

These dynamics rely on reciprocal activity: the vlogging YouTube stars are also subscribers to other channels, participants in discussions occurring within the YouTube community, and audiences for other YouTube videos; their audiences act as interlocutors, co-creators and critics by making related videos drawing on the YouTube stars' characters and material, leaving comments, or simply watching. Garnering this type of success requires more than knowledge of how YouTube's culture works; it also requires direct, ongoing participation within it. (105)

In this sense, inviting other successful YouTubers and using the \#YouTubeNegro hashtag are calculated strategies for gaining more visibility, more followers, more likes. This positive visibility is one of the most fundamental elements of what black women YouTubers are accomplishing through the success of their channels. As Joyce Fernandes, a popular rapper from Santos, São Paulo who performs under the name Preta-Rara, explains in a televised interview with Fátima Bernardes: “A gente ficou muito tempo invisível nessa sociedade, então se eu tenho esse cabelo aqui dessa cor, o batom dessa cor, é para ser vista, porque a gente está cansada de ser invisível na sociedade.” Preta-Rara's visibility goes beyond her aqua box braids and bright blue lipstick, as she used her own hashtag movement, \#EuEmpregadaDomestica, to bring awareness to the stories of thousands of domestic workers, most of them also black women, on the Facebook page she started in July 2016.

The centrality and importance of visibility so defined is a recurring theme on the forty channels and can be linked to the valorization of a black aesthetic that is present on all of the channels and central to the most popular ones. "Mulheres negras e autoestima," the fifth video in Neri's YouTube Negro series, features YouTubers Joyce Gervaes (channel Joyce Show) and Tati Sacramento. The topic 
for the video is aesthetics and learning how to feel good about one's body as a black girl or woman given the lack of positive references, for example in the media. The three women agreed that their own presence on YouTube, inspired by others like them, is helping to change the types of images available to themselves and other black women and girls. Sacramento explains: "Acho que a Internet possibilitou isso, a coisa da representatividade que a gente não tinha, com a Internet começou a se ver várias meninas e entender que não existe um padrão, né.” Later in the video, Gervaes admits: “Quando eu ligo a TV e não me vejo, vou no YouTube.” These thoughts illustrate how black women YouTubers are consciously carving out spaces for themselves, where there previously was none, or close to none. Due to the notorious limits of representativity of black women in Brazil, these YouTubers are turning to making their own content that affirms and empowers themselves, their bodies, and their aesthetics, conscious also that this has the potential to serve as a positive reference for other women and girls.

In an act of fortalecimento, Neri and her two guests close the video by looking directly into the camera and saying in unison: "Porque juntas nós somos mais fortes!” Again, Neri makes an explicit gesture to viewers in an ongoing interaction, not just amongst creators, but between creators and their subscribers. This interaction is brought full circle in the comments sections of each of the videos, which are overwhelmingly positive. For example, Isabela Campos comments: "não tô sabendo lidar com essa série de vídeos de conteúdo negro. Só gente maravilhosa. Amei o vestido da Tati.” Sacramento promptly responded to this, writing: "sua linda!!! Lindo né?! A ocasião mereceu... <3.” In this manner, videos that are meant to empower black women to feel confident in their appearance creates a community that further contributes to this forging of selfesteem through compliments to the creators.

Sacramento also did a couple of videos with fellow YouTubers for Black November. Her channel has all kinds of lifestyle videos in addition to vlogs showing her daily life with her family, in addition to personal opinion monologue videos. For Black November she uploaded two videos with the theme "Acredita Preta," one with Gabi de Oliveira (channel "DePretas”) and the other with Maíra Azevedo (channel “Tia Má”). The topic was self-esteem and what it means to be beautiful. The consensus was that inner beauty would shine through and make a person attractive to others. Many of Sacramento's videos focus on physical 
fitness: twenty-minute workouts, toning for abs and glutes, recipes for healthy eating, etc. In her conversations with Oliveira and Azevedo, she emphasized her promotion of healthy exercise and diet were aimed at improving physical wellness, not at attaining a particular beauty standard of thinness, recognizing the prevalence of prejudice against women, especially black women, with larger body types.

Channels like Sacramento's that focus on black women's wellness are important, especially given the disproportionately poor health care available for these women in Brazilian society (Beato; Caldwell; Carneiro; Roland; Werneck, Mendonça and White; Batista, Werneck and Lopes). Sueli Carneiro, for example, lists the need to address healthcare issues facing black women as one of the pillars of the movement (123-24), and Kia Caldwell explores the persistent structural barriers to health equality for black women. As women are not able to rely on the Brazilian healthcare system to consistently meet their wellness needs, tools of self-care including healthy eating and exercise information that channels like Sacramento's provide become increasingly valuable. In a country where healthcare, housing, and job market structures largely shorten black women's lifespans and reduce their quality of life, caring for the health of these women's bodies becomes an act of anti-racist resistance on its own.

One of the potential limits of the kind of psychological empowerment present on channels that emphasize self-acceptance through attention to hair and beauty is the level of consumerism that is built into many videos. Channels that include makeup or hair tutorials have a significant amount of product placement. The more successful channels are also more likely to make agreements with companies or websites that will send them free products including makeup, hair products, or even clothes and bags so that the YouTuber will feature the products and links in their videos. This constant advertisement is in addition to the YouTube ads themselves that the monetized channels include. However problematic, this can still be seen as black women allowing themselves access to participate in the rewards of capitalism that are usually reserved for white people or the already wealthy. From this perspective, black people who take control of capital for their own benefit and to improve quality of life for themselves and their families are inverting a system that normally exploits their labor for the gain of others. In this way, they use the master's tools "to beat him at his own game," as suggested by Audre Lorde (102). However, Lorde emphasizes that those "tools 
will never dismantle the master's house," and that "they will never enable us to bring about genuine change,” (102). This much is clear in research about black women and entrepreneurship, such as Adia Harvey Wingfield's study of hair salon owners in the United States. Due to the barriers to black women achieving socioeconomic mobility through the traditional job market, many are pushed into entrepreneurship. While this may offer some advancement, it is still limited in terms of the larger gendered racist society that inhibits financial growth or stability for black populations (Wingfield).

Neri is fairly self-reflexive and critical of capitalism, a feature best exemplified in the seventh video of the YouTube Negro series, "Negros e Ascensão,” with guest YouTuber Ana Paula Xongani, who is a small business owner. They problematize the notion of working within a capitalist system to empower themselves and their communities economically, given that capitalism works to ascribe greater and lesser value to different groups of people. They ask, for example, if the accumulation of capital by black women could lead to them becoming the oppressor, or if no matter how much individual black people "ascend," whether economically, socially or culturally, they would never be able to sway the balances of power.

This reflection on class positioning is essential to consider when thinking about the scope of YouTube representations, which, however diverse and necessary they may be to expanding a limited, stereotyped image of black women, is itself somewhat limited to a section of young viewers who are largely part of the expanded middle class. Most of the women are college educated and/or professionals, and their stories do not reflect the majority of black women in Brazil, who continue to face social and economic barriers to attaining higher education. This is particularly the case for rural populations, who likely would not even be able to access the videos analyzed here. As stated above, ease of access to Internet has steadily improved, and mobile technology has been a large contributing factor to this increase, but still just $64.7 \%$ of Brazilians over age ten use the Internet (“Acesso à Internet [...] análise” 27), and rural populations (who are mostly black) make up the majority of Brazilians without Internet ("Acesso à Internet [...] análise” 27).

A final YouTube channel exemplary of fortalecimento is "Estaremos Lá," which also made a Black November video. "Estaremos Lá" was created in the summer of 2016 by four friends following a racist incident they experienced 
while at a shopping mall. One of the creators, Stella Yeshua, offered to help a white woman who had dropped her full tray in the food court and the woman asked her to clean up the mess, assuming she was an employee, not a fellow shopper. Immediately following the incident, the four friends went into the women's restroom and produced their first video initially to express their anger. The video indeed leaves the viewer indignant about the incident, but it is also humorous and cleverly done. The presence and complete support of Yeshua's three friends as the four of them collaborate to make the video serve as a healing process after suffering from direct racism. At the end of the video, Yeshua and her friends send an important message to anyone who might think that the only reason for black women like them to be in a shopping mall is to clean up after white people: "Estaremos lá." Spaces that continue to be considered white spaces like shopping malls, airports, beaches in well-to-do areas, universities, and upscale restaurants are frequented by black people, not just as cleaners and servers, but as paying customers and knowledge producers. Yeshua and her friends warn viewers to get used to this reality. The implicit message to black viewers is that they do belong in these spaces of privilege and they will not be there alone, fortalecidas by the "we" created by the expression "We'll be there." The video was originally posted to Facebook, but went viral, inspiring the four friends to create their own YouTube channel.

In their November Negro video, the four hosts invited six white YouTubers to participate in a quiz show about black history in Brazil, as an educational experience for all. Not knowing the answer resulted in a pie in the face. Once again, the YouTubers of "Estaremos Lá" utilized the strategy of inviting fellow YouTubers to participate in a collaborative video to generate more visibility for their channel and likes for their video. In keeping with a theme in which Yeshua and her companions seem to address a white audience in many of their videos as a way to point out examples of racism to them, hoping to educate white viewers in order to potentially prevent them from engaging in the same type of discriminatory practice, this video reveals gaps in knowledge about black history. The mood is light and fun, and ignorance about black history comes with a comical consequence, but the videos end up conferring value to this area of knowledge and critiquing the lacunae in the education system that erases black agents of history. 
YouTube and vlogging offers a highly visible platform for black women to tell their own stories and share about the topics that matter to them with a community of viewers and fellow content creators. Whether they are valorizing a black aesthetic, promoting self-care of a black female body, or tackling issues of racism, sexism and homophobia head on, YouTubers offer an important alternative of a diverse representation of what it means to be a black woman in twenty-first-century Brazilian society.

\section{Creating Black Spaces}

The Novembro Negro series was filmed in the now-defunct YouTube Space in São Paulo, which was funded by Instituto Criar, the NGO owned by Brazilian television personality and multimillionaire Luciano Huck. Neri utilized the YouTube Space, which was open from 2014 until the opening of the new YouTube Space in Rio de Janeiro in August 2017, precisely to offer an alternative to the kind of mainstream content offered on Huck's popular program "Caldeirão do Huck," which airs on Globo. By using the studio and equipment in the YouTube Space funded by Huck, a symbol of wealth, whiteness and conservatism, Neri occupied a space of symbolic whiteness and transformed it into an engine of creativity, black representativity, black intellectual discussion, and all-around unapologetic blackness.

In addition to the YouTube Space, Neri calls attention to the importance of other physical spaces, beyond the virtual community of the channels. Also during the month of November, Neri was invited to the Instituto Mídia Étnica in Salvador, Bahia. This is a physical space run by an NGO in Salvador that provides technological tools and training for different community organizations with the intention of improving racial diversity and inclusion in Brazilian media. The space was also visited by YouTuber Xongani around the same time. Both Neri's and Xongani's videos highlighted the importance of having a physical space available for learning, production, and networking, showcasing the way communities are built both online and offline. I visited the Instituto Mídia Étnica myself in 2017 and 2018, attended several of their events, and had lengthy conversations with Donminique Azevedo, a journalist who works for Correio Nagô, a news website housed within the Instituto Mídia Étnica. In 2018, the Instituto had acquired an additional space inside one of Salvador's largest 
shopping malls to provide a larger array of events and classes for the public. Through my experiences in both spaces, I found the Instituto to be a dynamic and vibrant space of collaboration that was key to supporting a variety of online activities such as Correio Nagô's own YouTube channel.

The Instituto Mídia Étnica (IME) takes up a four-story building centrally located near downtown Salvador. The only thing setting the large metal door apart from the others on the narrow cobblestone street is a small VOJO sticker. ${ }^{1}$ Once inside, a long staircase straight ahead ascends to the floors above, while a door to the left leads to the office space on the ground floor. Going through the door reveals several computer workspaces with large whiteboards and calendars on the walls showing evidence of brainstorming and many planned events. This is where the journalists of Correio Nagô do their research and write their articles. On the floor above is the editing suite for video projects either of the IME's design or for use by the public to create their own media projects. The top floor of the building boasts a small kitchen and an ample event space. During the day, this sun-bathed area could serve as a general meeting space. In the evenings, it accommodates a variety of events and activities, including film screenings, poetry readings, and workshops of all kinds.

Each July, organizations across Salvador, and Brazil, commemorate Julho das Pretas, inspired by the Dia Internacional da Mulher Negra Latino-Americana e Caribenha celebrated on July 25. During July 2017, I was able to participate in numerous events in both Rio and Salvador that highlighted the need for awareness and action related to issues facing black women. In Salvador, many of those events are coordinated by a black feminist organization called Odara: Instituto da Mulher Negra. One of the most memorable of these events was hosted by the IME. That night, the top floor filled with black lesbian or queer women and a few white allies. The women were mostly college-age or slightly older, with a few exceptions. The women came together for a viewing of a documentary, Eu sou a próxima, which related stories of feminicide of black lesbian women living in São Paulo's peripheries. The documentary was created by the Coletiva Luana Barbosa, named after a black lesbian woman who was

\footnotetext{
${ }^{1}$ VOJO is a service that that makes it possible to access the Internet with a regular phone with the goal of increasing Internet accessibility, particularly in rural areas with limited Internet or cellular service.
} 
beaten to death by police in 2016 in her own neighborhood in front of friends, neighbors, and her son, whom she was taking to school.

The sequence of activities for the evening was structured with careful attention to the need for healing and self-care of the women in attendance. The disturbing and horrific narratives of death and violation were presented sensitively and impactfully. For the black, lesbian women from periphery neighborhoods who gathered to view the documentary each account was a reminder that they could quite literally be the next one. Recognizing the difficulty of the topic, especially for anybody who had already experienced misogynist or homophobic violence or lost a loved one to police brutality, the event organizers allowed for a moment of quiet reflection after the film finished. Some viewers took the opportunity to use the restroom, or to get some fresh air or a coffee to process the heaviness of the stories. Shortly afterward, the group came back together for a discussion with a couple of members of the Coletiva Luana Barbosa who had traveled to Salvador from São Paulo for the screening. After the discussion, the event became a poetry reading and ended with a lively and uplifting musical performance. By the end of this evening of sharing, poetry, and music, everyone in attendance felt a sense of togetherness and healing. By allowing for reflection, sharing personal experiences with a sympathetic group, and expressing joy through poetry and music, the organizers of the event at the IME crafted an evening of healing in the face of a difficult topic that could cause women to relive traumas. The attentiveness to content, how the body responds to that content, and the creation of opportunities of coming together even among strangers follows a pattern of a methodology practiced by black women as they conceptualize events for themselves that I witnessed repeatedly by multiple groups of women in Salvador, Rio de Janeiro, and São Paulo.

The potency of this event highlights the necessity of physical spaces for gathering like those provided by the IME. While the IME's work is largely visible through online manifestations, on their website, their social media accounts, and through videos they produce and share, their true mission is their ability to provide a physical space, access to media technology and media training for the community. Without the brick and mortar structure in downtown Salvador, this content would not be of the same quality or have the same reach. Furthermore, events like the one I attended with the Coletiva Luana Barbosa demonstrate the value of extending online conversations to personal encounters and how these in- 
person gatherings can provide a space of healing and togetherness for black women. Through occupying web space and physical spaces, black women in Brazil contest the marginalization of black creativity and representation, building their own narratives and sharing them with their communities.

\section{Conclusion}

On October 28, 2018, Jair Bolsonaro won the Brazilian presidential runoff election. Throughout his career as an army captain and congressman, Bolsonaro has firmly expressed racist, misogynist, and homophobic beliefs as well as support for a return to a military regime in Brazil, lifting restrictions on firearms for the public, and further militarizing police forces as a way to combat crime.

In the face of the uncertainty that Bolsonaro's electoral victory brought to groups targeted by the hate speech of the president-elect, many black women in Brazil once again resorted to strategies that would allow them to survive this most recent affront to their ability to exist without fear. Images and texts circulated on Facebook and Instagram, in which black women encouraged each other to stand tall and continue the struggle against sexualized racism and racialized sexism. Many women shared a quote from Conceição Evaristo: "Eles combinaram de nos matar, mas nós combinamos de não morrer.” The day after the election, Sacramento uploaded a video to YouTube. Still in her bathrobe and slightly hoarse, she spoke in an even, calm tone sharing her response to the result. As she addressed her YouTube audience, she stood in her kitchen and prepared a vegan orange cake, sharing the recipe in the description of the video. Through this simple act, Sacramento performed a multi-faceted act of fortalecimento for herself and her viewers. First, she found an outlet for her own anxiety and fear in relation to the outcome of the election, both through the act of preparing the cake (She stated in the video that cooking is an important release for her when she feels stressed.), and by talking through her thoughts out loud. Next, she continued her regular practice of radical self-care and radical self-love by preparing food that would be good for her and her family in the context of the difficulties of black family life in Brazil. Finally, Sacramento created a resource for her YouTube community in the form of a healthy recipe and an intimate kitchen conversation about a topic of great concern with which her viewers could identify. In the face of the hostility of the incoming administration, Sacramento 
Perrine

demonstrated how black women in Brazil continue to resist the forces at work against them during a particularly difficult time.

As women on YouTube continue to create dynamic content that multiplies representations of black womanhood in Brazilian visual media culture, scholars should continue to pay attention to how this production works to shift meanings attached to race and gender. The vast amount of content relating to black haircare, for example, is an ample avenue for future research about the strategies of fortalecimento that women use to claim pride in their bodies and hair, both for themselves and for other women and girls. Such studies will be essential for drawing attention to the creative and intellectual force of black women using collective practices to strengthen themselves in the face of rampant racism and sexism.

\section{Works Cited}

Afroflix. www.afroflix.com.br/, Accessed 8 Dec. 2016.

Ali, Amir Hatem. "The Power of Social Media in Developing Nations: New Tools for Closing the Global Digital Divide and Beyond.” Harvard Human Rights Journal, vol. 24, 2011, pp.185-219.

Batista, Luís Eduardo, Jurema Werneck, and Fernanda Lopes, organizers. Saúde da população negra. Associação Brasileira de Pesquisadores Negros, 2012.

Beato, Lucila. “Inequality and Human Rights of African Descendants in Brazil.” Journal of Black Studies, vol. 34, no. 6, 2004, pp. 766-86.

Berth, Joice. O que é empoderamento? Letramento, 2018.

Blogueiras negras. www.blogueirasnegras.org/, Accessed 8 Dec. 2016.

Bonilla, Yarimar, and Jonathan Rosa. "\#Ferguson: Digital Protest, Hashtag Ethnography, and the Racial Politics of Social Media in the United States.” American Ethnologist, vol. 42, no. 1, 2015, pp. 4-17.

Burgess, Jean, and Joshua Green. "The Entrepreneurial Vlogger: Participatory Culture Beyond the Professional-Amateur Divide.” The YouTube Reader, edited by Pelle Snickars and Patrick Vondereau. Wallflower, 2009.

Caldwell, Kia Lilly. Health Equity in Brazil: Intersections of Gender, Race, and Policy. U of Illinois P, 2017. 
Campos, Isabela. Comment on "Mulheres negras e autoestima-com Joyce Gervaes e Tati Sacramento.” YouTube, uploaded by Afros e Afins, 16 Nov. 2016, www.youtube.com/watch?v=PrtZRYHgsKU.

Carneiro, Sueli. “Mulheres em movimento.” Estudos Avançados, vol. 17, no. 49, 2003, pp. 117-32.

Correio Nagô. www.correionago.com.br/, Accessed 15 Oct. 2019.

Dijck, José Van. The Culture of Connectivity: A Critical History of Social Media. Oxford UP, 2013.

Elza. A mulher do fim do mundo. Circus, 2015.

Eu sou a próxima. Coletiva Luana Barbosa, 2017.

Fisher, Stacy. “The Top 10 Most Popular Sites of 2020.” Lifewire, 2 Jan. 2020, www.lifewire.com/most-popular-sites-3483140.

Gabriel, Deborah. "Blogging While Black, British and Female: A Critical Study on Discursive Activism.” Information, Communication \& Society, vol. 19, no. 11, 2016, pp. 1622-35.

Gervaes, Joyce, and Tati Sacramento. "Mulheres negras e autoestima—com Joyce Gervaes e Tati Sacramento.” YouTube, uploaded by Afros e Afins, 16 Nov. 2016, www.youtube.com/watch?v=PrtZRYHgsKU.

Holmes, Tori. "Reframing the Favela, Remapping the City: Territorial Embeddedness and (Trans) Locality in 'Framing Content' on Brazilian Favela Blogs.” Journal of Latin American Cultural Studies, vol. 25, no. 2, 2016, pp. 297-319.

Lorde, Audre. Sister Outsider: Essays and Speeches. Crossing, 2007.

Mundo Negro. www.mundonegro.inf.br/, Accessed 8 Dec. 2016.

Nask, Débora, and Marcos Pereira. "Entenda o empoderamento negro didaticamente.” Revista Afirmativa, 28 Mar. 2019, www.revistaafirmativa. com.br/entenda-o-empoderamento-negro-didaticamente/.

Nemer, David. "Online Favela: The Use of Social Media by the Marginalized in Brazil.” Information Technology for Development, vol. 22, no. 3, 2016, pp. 364-79.

Neri, Nátaly. "Negros e ascensão: com Ana Paula Xongani \#YouTubeNegro.” YouTube, uploaded by Afros e Afins, 18 Nov. 2016, www.youtube.com/ watch?v=70p6HwFdShY\&t=483s. 
Pesquisa Nacional por Amostra de Domicílios Contínua. Acesso à internet e à televisão e posse de telefone móvel celular para uso pessoal: 2014. Instituto Brasileiro de Geografia e Estatística, 2016.

- Acesso à internet e à televisão e posse de telefone móvel celular para uso pessoal: análise dos resultados. Instituto Brasileiro de Geografia e Estatística, 2018.

Preta-Rara. "Eu Empregada Doméstica.” Facebook, www.facebook.com/ euempregadadomestica/.

—. "Rapper cria campanha para denunciar maus-tratos sofridos por domésticas.” Interview with Fátima Bernardes, Globo Play, 8 Dec. 2016, globoplay.globo.com/v/5195249/.

Ribeiro, Djamila. O que é lugar de fala? Letramento, 2018.

Roland, Edna. "Direitos reprodutivos e racismo no Brasil.” Estudos Feministas, vol. 3, no. 2, 1995, pp. 506-14.

Sacramento, Tati. “Ele ganhou e agora?!” YouTube, uploaded by Tati Sacramento Oficial, 29 Oct. 2018, www.youtube.com/watch?v= Ytu7J7qJCuI.

—. “'Não sou bonita’...: Novembro Negro | Acredita Preta com Tia Má | Tati Sacramento.” YouTube, uploaded by Tati Sacramento, 20 Nov. 2016, www.youtube.com/watch?v=bKW0V6F2Sbg.

—. "Porque você é bonita! | Acredita, Preta! com Gabi Oliveira | \#NovembroNegro | Tati Sacramento.” YouTube, uploaded by Tati Sacramento, 1 Nov. 2016, www.youtube.com/watch?v=mndh8DdtK Do\&t $=64 \mathrm{~s}$.

Sierra-Rivera, Judith. “Afro-Cuban Cyberfeminism: Love/Sexual Revolution in Sandra Álvarez Ramírez’s Blogging.” Latin American Research Review, vol. 53, no. 2, 2018, pp. 330-43.

Sobande, Francesca. "Watching Me Watching You: Black Women in Britain on YouTube.” European Journal of Cultural Studies, vol. 20, no. 6, 2017, pp. 655-71.

Spiro, Emma S. and Andrés Monroy-Hernández. "Shifting Stakes: Understanding the Dynamic Roles of Individuals and Organizations in Social Media Protests.” PLoS ONE, vol. 11, no. 10, 2016, e0165387. 
Steele, Catherine Knight. "Black Bloggers and Their Varied Publics: The Everyday Politics of Black Discourse Online.” Television and New Media, vol. 19, no. 2, 2018, pp. 112-27.

Werneck, Jurema, Maisa Mendonça, and Evelyn C. White, organizers. O livro da saúde das mulheres negras: nossos passos vêm de longe. Criola, 2000.

Wingfield, Adia Harvey. Doing Business with Beauty: Black Women, Hair Salons, and the Racial Enclave Economy. Rowman \& Littlefield, 2008.

Xongani, Ana Paula. "Xongani em Salvador-EP 1/2—venha conhecer o Inst. Mídia Étnica!” YouTube, uploaded by Ana Paula Xongani, 25 Nov. 2016, www.youtube.com/watch?v=JI7cHk1OTsM.

Yeshua, Stella, Carol Silvanno, Samantha Cristina, e Beatrice Oliveira. "Quem ‘quiz' vai saber \#youtubenegro.” YouTube, uploaded by Estaremos lá, 20 Nov. 2016, www.youtube.com/watch?v=KFOo8SIB7pY.

—. “Se é negro... Tem que me servir?” YouTube, uploaded by Estaremos Lá, 9 Aug. 2016, www.youtube.com/watch?v=UcvGF2SYWkY. 